\title{
Antioxidant and hemolytic activity of Ziziphus jujuba Mill and Rhamnus alaternus L (Rhamnaceae) extracts from Algeria.
}

\section{Activité antioxydante et hémolytique des extraits de Ziziphus jujuba Mill et Rhamnus alaternus (Rhamnaceae) d'Algérie.}

Manuscrit reçu le 26 mars 2020 et accepté le 2 avril 2020

\author{
Tarik Mohammed ChaOuChe, Farah Haddouchi ${ }^{1}$, Ouhiba BoudjemaI, \\ and Imane GHELLAI
}

Laboratory of Natural Products, Department of Biology, Abou Bekr Belkaïd University, BP 119, Tlemcen, 13000, Algeria

\section{Résumé}

Introduction et objectif : Les antioxydants naturels font l'objet de nombreux travaux en plus de leur utilisation comme conservateurs dans les aliments; ils sont également impliqués dans le traitement de nombreuses maladies. Dans le cadre de l'étude prospective de sources intéressantes d'antioxydants d'origine naturelle, nous sommes intéressés à deux plantes médicinales de la famille des Rhamnaceae : Ziziphus jujuba Mill et Rhamnus alaternus L.

Matériel et méthode s: Des extractions à reflux à l'acétone et au méthanol ont été réalisées en vue de quantifier les composés phénoliques et d'évaluer l'activité antioxydante par deux méthodes : piégeage du radical $\mathrm{DPPH}^{\circ}$ et réducteur de fer. Un test hémolytique a été réalisé pour déterminer la cytotoxicité des extraits.

Résultats : Les résultats obtenus montrent que les teneurs en polyphénols sont comprises entre $0,64 \pm 0,03$ et $2,05 \pm 0,1 \mathrm{mg} \mathrm{GAE} / \mathrm{g} \mathrm{MS}$ et les teneurs en flavonoïdes et tanins varient de $0,01 \pm 0,001$ à $0,99 \pm 0,01 \mathrm{mg} \mathrm{EC} / \mathrm{g} \mathrm{MS}$ et de $0,55 \pm 0,01$ à $7 \pm 0,2 \mathrm{mg} \mathrm{EC/g} \mathrm{MS}$ respectivement. Tous les extraits des plantes étudiées présentent des propriétés antioxydantes à différentes concentrations, avec une meilleur activité pour les feuilles de $R$. alaternus, mais celles-ci sont strictement inférieures au BHA pris comme référence tous les extraits étudiés représentent un effet hémolytique inférieur à $3.5 \%$ qui caractérisent une hémolyse très faible. Conclusion: Ces plantes ont une activité antioxydante modeste et elles ne sont pas toxiques.

Mots clés: Plantes médicinales, polyphénols, flavonoïdes, tanins, activités antioxydantes, $\mathrm{DPPH}^{\circ}$, réduction en fer, test hémolytique.

\section{Abstract}

Background and Objective: The natural antioxidants are the subject of numerous studies in addition to their use as preservatives in food; they are also involved in the treatment of many diseases. In the context of the prospective study of interesting sources of antioxidants of

\footnotetext{
${ }^{1}$ Email: farah.haddouchi@,univ-tlemcen.dz
} 
natural origin, we are interested in two medicinal plants from the Rhamnaceae family: Ziziphus jujuba Mill and Rhamnus alaternus L.

Materials and methods: Reflux extractions with acetone and methanol were carried out in order to quantify the phenolic compounds and to evaluate the antioxidant activity by two methods: trapping of the $\mathrm{DPPH}^{\circ}$ radical and iron reducer. A hemolytic test was carried out to determine the cytotoxicity of the extracts.

Results: The results obtained show that the polyphenol contents are between $0.64 \pm 0.03$ and $2.05 \pm 0.1 \mathrm{mg} \mathrm{GAE} / \mathrm{g} \mathrm{DM}$ and the flavonoid and tannin contents vary between $0.01 \pm 0.001$ to $0.99 \pm 0.01 \mathrm{mg} \mathrm{EC} / \mathrm{g} \mathrm{DM}$ and $0.55 \pm 0.01$ to $7 \pm 0.2 \mathrm{mg} \mathrm{EC} / \mathrm{g} \mathrm{DM}$ respectively. All the extracts from the plants studied have antioxidant properties at different concentrations, with better activity for $R$. alaternus L leaves, but these are lower than the BHA taken as reference. All the extracts studied represent a hemolytic effect of less than $3.5 \%$, which characterize very low hemolysis.

Conclusion: These plants have modest antioxidant activity and are not toxic.

Key words: Medicinal plants, polyphenols, flavonoids, tannins, antioxidant activities, $\mathrm{DPPH}^{\circ}$, iron reduction, hemolytic test.

\section{INTRODUCTION}

Secondary metabolites constitute a variety of useful substances for the treatment of certain human diseases. This may explains why even today, most people in Africa rely on herbal medicine for treatment. According to the World Health Organisation, more than $80 \%$ of African populations use traditional medicine and pharmacopoeia for their primary health care [1, 2]. Among various medicinal plants, some endemic and edible species are of particular interest because they may be used for producing raw materials or preparations containing phytochemicals with significant antioxidant capacities and high content of minerals with health benefits. Herbs are used in many domains, including medicine, nutrition, flavouring, beverages, dyeing, repellents, fragrances and cosmetics [3]. Ziziphus jujuba Mill is a fruit tree belonging to the Rhamnaceae family; it is mainly distributed in the subtropical and tropical regions of Asia and America. This plant is rich in bioactive components like vitamin C, flavonoids, triterpenoids and polysaccharides [4]. It is used in traditional Chinese and Korean medicine as antifungal, antibacterial, antiulcer, anti-inflammatory and antioxidant remedies [5]. Rhamnus alaternus $L$ belongs to the family of Rhamnaceae, it is a perennial dioecious shrub distributed throughout the Mediterranean basin. The therapeutic uses of the species $R$. alaternus $\mathrm{L}$, have been demonstrated in vitro, they are due to active compounds such as polyphenols. The leaves are used as a laxative, purgative, hypotensive and to treat dermatological and liver diseases [6]. Red blood cells are among the most sensitive cells to free radicals. In fact, during oxidative stress, free radicals induce early aging of red blood cells, thereby promoting their abnormal destruction, which may lead to hemolytic anaemia [7]. One of the ways to address these oxidative stress-related diseases lie in more in-depth research on medicinal plants to promote their therapeutic properties including antioxidant activities in the prevention and fight against oxidative stress. In this context, our objective is devoted to the phytochemical study and to the evaluation of the antioxidant activity and the hemolytic power of two local plants, Ziziphus jujuba Mill and Rhamnus alaternus L, which 
have several properties which make its study interesting. They are two plants of the same family, they grow spontaneously and their uses are very widespread in traditional Algeria medicine.

\section{MATERIALS AND METHODS}

\subsection{Plant material}

The plant materials used in our study are represented by the seeds and fruit of Ziziphus jujuba Mill and leaves and bark of the stems of Rhamnus alaternus $L$ which have been harvested during the month of November 2019 in the Ouzidane region, Wilaya of Tlemcen (Algeria). The 4 parts of plants were dried for two weeks under the shade and ground into a fine powder.

\subsection{Extract preparation}

After grinding the vegetable matter (the seeds and fruit of Z. jujuba and leaves and bark of the stems of $R$. alaternus $\mathrm{L}$ ), reflux extractions were used with a methanol / acetone solvent $(60 \% / 40 \%)$, for 1 hour, in order to obtain the different extracts studied. The extracts were finally filtered through Whatman filter paper, concentrated at reduced temperature (below $50{ }^{\circ} \mathrm{C}$ ) by rotary evaporation and recovery of solid products.

\subsection{Quantification of phenolic classes}

\subsubsection{Determination of total phenol contents}

$100 \mu \mathrm{l}$ of each extract at a concentration of $1 \mathrm{mg} / \mathrm{ml}$, and mixed with $2 \mathrm{ml}$ of a sodium carbonate ( $2 \%)$ solution freshly prepared, the whole is agitated with a vortex. After 5 min, $100 \mu \mathrm{l}$ of the Folin-Ciocalteu reagent diluted $(1 / 20)$ was added and the mixture was incubated in total darkness for $30 \mathrm{~min}$ at room temperature, the absorbance was read at $700 \mathrm{~nm}$ versus the prepared blank. Different concentrations of gallic acid were used to prepare a calibration curve. Results were expressed as milligram gallic acid equivalents (GAE)/g DM [8].

\subsubsection{Determination of flavonoid contents}

$250 \mu \mathrm{l}$ of each extract at a concentration of $1 \mathrm{mg} / \mathrm{ml}$, is mixed with $75 \mu \mathrm{l}$ of sodium nitrite $(5 \%)$ with as incubate for $6 \mathrm{~min}$ at room temperature, by adding $150 \mu \mathrm{l}$ of aluminium chloride $\left(6 \mathrm{H}_{2} \mathrm{O}\right)$ at $10 \%$, after 5 min $1 \mathrm{M}$ of sodium hydroxide solution $(500 \mu)$ was added to each extract and the final volume was adjusted to $2.5 \mathrm{ml}$ with distilled water and thoroughly mixed. Absorbance of the mixture was determined at $510 \mathrm{~nm}$. Results were expressed as milligram quercetin equivalents/g of dry weight (mg QE/g DW) [9].

\subsubsection{Determination of total condensed tannins}

$500 \mu \mathrm{l}$ aliquots of prepared extracts were added to $3 \mathrm{ml}$ of vanillin solution (4\%) and $1.5 \mathrm{ml}$ of concentrated sulfuric acid respectively, the mixture was allowed to stand for $15 \mathrm{~min}$ at room temperature $\left(25^{\circ} \mathrm{C}\right)$ and the absorption was measured at $500 \mathrm{~nm}$ against solvent as a 
blank. Results were expressed as milligram (+)-catechin equivalents/g dry weight $(\mathrm{mg} \mathrm{CE} / \mathrm{g}$ DW) [10].

\subsection{In vitro evaluation of antioxidant activity}

\subsubsection{Scavenging of the free radical DPPH}

At different concentrations, $50 \mu \mathrm{l}$ of each extract are added to $1950 \mu \mathrm{l}$ of a methanolic solution of 2,2-diphenyl-1-picrylhydrazyl (DPPH) at $6.3410^{-5} \mathrm{M}$. For each concentration, a blank is prepared. A negative control is prepared, in parallel, while mixing $50 \mu \mathrm{l}$ of methanol with $1950 \mu \mathrm{l}$ of a methanolic solution of DPPH at the same concentration used. After incubation in the dark for 30 minutes and at room temperature, the reduction in DPPH is accompanied by the change from purple to yellow in the solution. The absorbances are read at $515 \mathrm{~nm}$ using a spectrophotometer. The positive control used is butylated hydroxyanisole (BHA), and the radical scavenging activity was calculated as a percentage of DPPH discoloration using the equation:

\section{DPPH radical scavenging $(\%)=\left[\left(\mathrm{A}_{0}-\mathrm{A}_{1} / \mathrm{A}_{0}\right] \times 100\right.$}

Where $A_{0}$ and $A_{1}$ are the absorbance at $30 \mathrm{~min}$ of the positive control and the extract, respectively. The antiradical activity was expressed as $\mathrm{IC}_{50}(\mu \mathrm{g} / \mathrm{ml})$, this is the extract concentration required to cause a reduction of $50 \%$ to absorbance at $517 \mathrm{~nm}$. A lower IC50value corresponds to the extract effectiveness [11].

\subsubsection{Ferric reducing antioxidant potential (FRAP) assay}

$1 \mathrm{ml}$ of each extract at different concentrations with $2.5 \mathrm{ml}$ of $0.2 \mathrm{M}$ phosphate buffer at $\mathrm{pH}=6.6$ and $2.5 \mathrm{ml}$ of a $1 \%$ potassium ferricyanide solution. The mixture obtained is incubated for 20 minutes at $50{ }^{\circ} \mathrm{C}$, and then $2.5 \mathrm{ml}$ of $10 \%$ trichloroacetic acid are added to stop the reaction. The mixture is centrifuged at $650 \mathrm{~g}$ for ten minutes at room temperature and $2.5 \mathrm{ml}$ of the supernatant are added to $2.5 \mathrm{ml}$ of distilled water and $0.5 \mathrm{ml}$ of $0.1 \%$ iron chloride. The absorbance is read at $700 \mathrm{~nm}$ against a blank. The results make it possible to calculate the effective concentration $\left(\mathrm{EC}_{50}\right)$, concentration of the extract corresponding to an absorbance equal to 0.5 , the linear regression curve (density of the optics as a function of the different concentrations). The activity of the extract is finally compared with that of the positive control (BHA) [12].

\subsection{Hemolytic activity}

In hemolysis tubes, $20 \mu \mathrm{l}$ of each extract at different concentrations are added to 1980 $\mu 1$ of the erythrocyte suspension prepared. These tubes then incubated at $37{ }^{\circ} \mathrm{C}$ for 60 minutes. These tubes are then incubated at $37{ }^{\circ} \mathrm{C}$ for 60 minutes. After incubation, samples of $250 \mu \mathrm{l}$ are taken for each tube to be taken up in $750 \mu \mathrm{l}$ of PBS. These are gently mixed and put in an ice bath to stop the reaction, then centrifuged at $2500 \mathrm{rpm}$ for 10 minutes. The absorbances are read at $548 \mathrm{~nm}$ using a spectrophotometer, against a blank containing PBS. Under the same conditions and the same experimental procedures, we have prepared a total hemolysis tube which contains $100 \mu \mathrm{l}$ of the erythrocyte suspension and $1900 \mu \mathrm{l}$ of distilled water and a 
negative control tube composed of $250 \mu \mathrm{l}$ of erythrocyte suspension and $750 \mu \mathrm{l}$ of PBS buffer solution [13]. The hemolysis rate of the different extracts is calculated as a percentage relative to the total hemolysis, after 60 minutes of incubation, according to the following formula:

Hemolysis rate $(\%)=[(\mathrm{DO}$ extract $-\mathrm{DO}$ negative control $) / \mathrm{DO}$ negative control $\} \times 100]$

\section{RESULTS}

\subsection{Quantification of phenolic classes}

\subsubsection{Determination of total phenol contents}

For the two parts of the plants studied by $Z$. jujuba and $R$. alaternus we noticed variations in the contents of total phenols. The highest content is found in the extract of $Z$. jujuba fruits, it is around $2.05 \pm 0.1 \mathrm{mg}$ GAE/g DM. For $R$. alaternus leaves is around $1.68 \pm 0.1 \mathrm{mg} \mathrm{GAE} / \mathrm{g}$ DM. followed by the seeds of $Z$. jujuba which have a total polyphenol content of $1.15 \pm 0.1 \mathrm{mg} \mathrm{GAE} / \mathrm{g} \mathrm{DM}$, and $0.64 \pm 0.03 \mathrm{mg} \mathrm{GAE} / \mathrm{g} \mathrm{DM}$ in the barks of $R$. alaternus.

\subsubsection{Determination of flavonoid contents}

For the two parts of the plants studied by $Z$. jujuba and $R$. alaternus we noticed variations in the flavonoid contents. The highest flavonoid content is found in the extract of the seeds of $Z$. jujuba, in the order of $0.99 \pm 0.01 \mathrm{mg} \mathrm{EC} / \mathrm{g} \mathrm{DM}$, followed by $R$.alaternus bark in the order of $0.58 \pm 0.02 \mathrm{mg} \mathrm{EC} / \mathrm{g} \mathrm{DM}$. We noted a low flavonoid content in the two extracts of the fruits of Z. jujuba $0.018 \pm 0.00 \mathrm{mg} \mathrm{EC} / \mathrm{g}$ MS and in the leaves of $R$. alaternus $0.014 \pm 0.00 \mathrm{mg}$ EC/g DM.

\subsubsection{Determination of total condensed tannins}

For the two parts of the plants studied by $Z$. jujuba and $R$. alaternus we noticed variations in the contents of condensed tannins. The highest content is found in the extract of the leaves of $R$. alaternus, in the order of $7 \pm 0.2 \mathrm{mg}$ EC/g DM, For $R$. alaternus bark it is $3.60 \pm 0.2 \mathrm{mg} \mathrm{EC} / \mathrm{g} \mathrm{DM}$, followed by $Z$. jujuba fruits which have a condensed tannin content of $3 \pm 0.2 \mathrm{mg} \mathrm{EC} / \mathrm{g} \mathrm{DM}$, and finally the seeds of $Z$. jujuba with a value of $0.55 \pm 0.01 \mathrm{mg}$ EC/g DM.

\subsection{In vitro evaluation of antioxidant activity}

\subsubsection{Scavenging of the free radical DPPH}

From the results shown in Figures 1 and 2 it appears that the percentage of inhibition of the free radical increases with increasing concentration either for the standard (BHA), or for the different plant extracts. It was noted that the percentage of inhibition of the free radical of all the extracts studied was lower than that of the BHA standard. For a concentration of 62 $\mu \mathrm{g} / \mathrm{ml}$ the BHA standard revealed a percentage of DPPH inhibition of $95.60 \%$. 


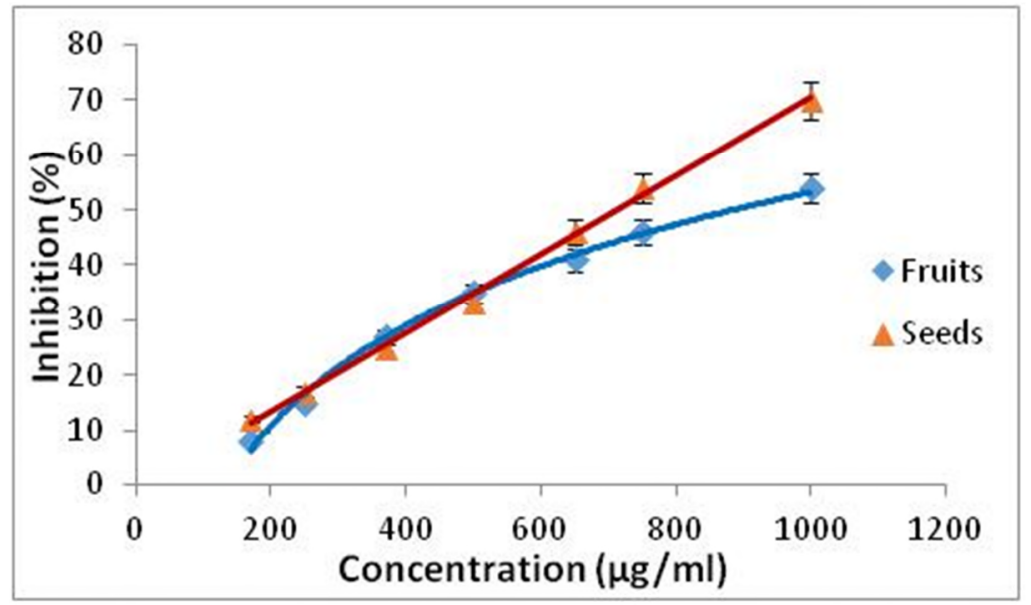

Figure 1: Percentage inhibition of DPPH as a function of the different concentrations of extracts from Z. jujuba.

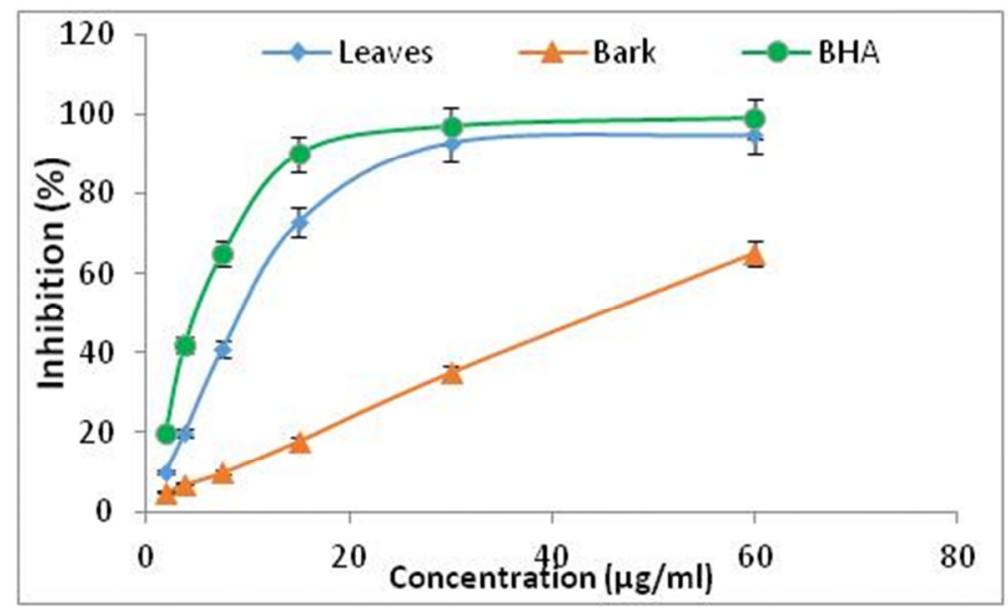

Figure 2: Pourcentage d'inhibition de la DPPH en fonction des différentes concentrations de BHA et d'extraits de $R$. alaternus.

Concerning the two extracts of $R$. alaternus, at the same concentration, the percentage of inhibition of DPPH is $95 \%$ of the extract of the leaves, while the extract of the barks is $59.58 \%$. For the two extracts of Z. jujuba, they have a lower DPPH trapping power than the other extracts, for a concentration of $750 \mu \mathrm{g} / \mathrm{ml}$ the percentage of DPPH inhibition is $46 \%$ of the fruit extract, while the seed extract is $51.26 \%$. The antioxidant efficacy of the different extracts was determined from the $\mathrm{IC}_{50}$ concentration (Table 1). 
Table 1: The antioxidant activities of the four crude extracts and of the standard by the DPPH method.

\begin{tabular}{ll}
\hline Extracts & $\mathbf{I C}_{\mathbf{5 0}}(\boldsymbol{\mu g} / \mathbf{m l})$ \\
\hline Z. jujuba Fruits & $845.6 \pm 6.1$ \\
Z. jujuba Seeds & $720.1 \pm 4.5$ \\
R. alaternus Leaves & $10.5 \pm 0.8$ \\
R. alaternus Bark & $51.2 \pm 1.2$ \\
BHA & $5.6 \pm 0.8$ \\
\hline
\end{tabular}

According to the $\mathrm{IC}_{50}$ values, the classification of the effectiveness of the extracts is as follows: BHA $>R$. alaternus leaves $>R$. alaternus bark $>Z$. jujuba seeds $>Z$. jujuba fruits. The extracts of $R$. alaternus $\mathrm{L}$ have a more promising activity than that of $Z$. jujuba Mill and the antioxidant activity of $R$. alaternus leaves are slightly lower than that of BHA. However the other extracts are significantly lower than that of BHA.

\subsubsection{Ferric reducing antioxidant potential (FRAP) assay}

The values of the optical densities as a function of the different concentrations made it possible to draw curves of each extract studied. The results shown in Figures 3 and 4 showed us that the reduction capacity is proportional to the increase in the concentrations used, either for the standard (BHA), or for the different extracts.

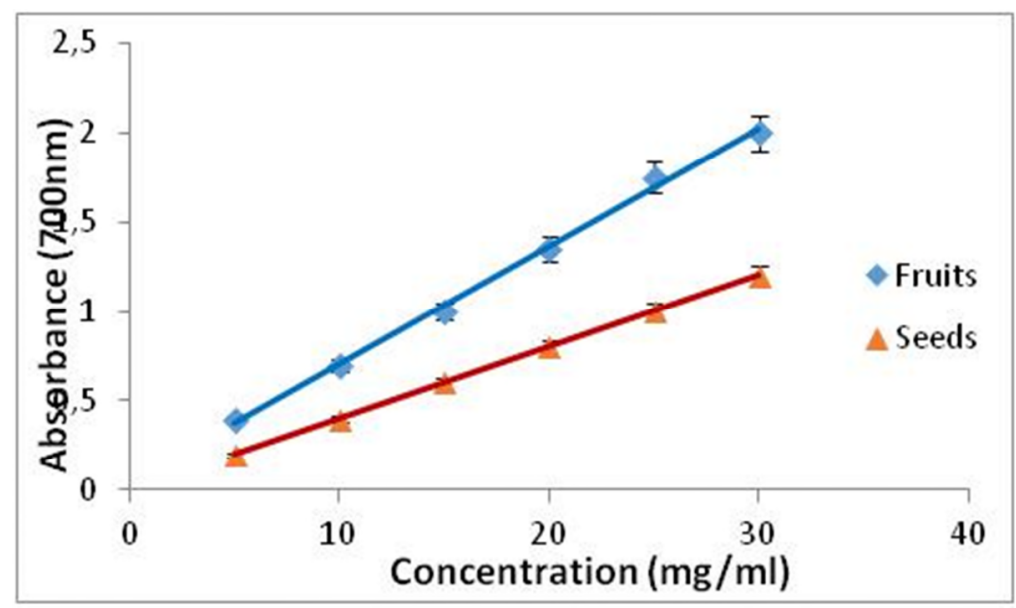

Figure 3: Reducing power of extracts from Z. jujuba 


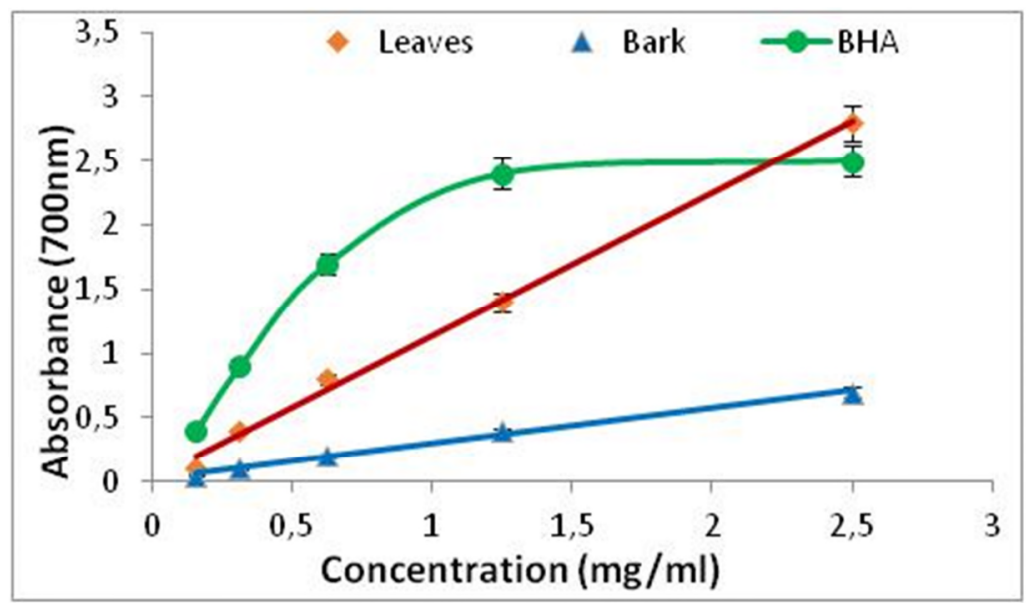

Figure 4: Reducing power of BHA and R. alaternus.

In order to compare the antioxidant activity of the extracts tested by this method, we calculated the $\mathrm{EC}_{50}$ concentration. The results obtained are illustrated in Table 2 .

Table 2: The antioxidant activities of the four crude extracts and of the standard by the FRAP method.

\begin{tabular}{lc}
\hline \multicolumn{1}{c}{ Extracts } & EC $_{\mathbf{5 0}} \mathbf{( m g / m l )}$ \\
\hline Z. jujuba Fruits & $6.9 \pm 0.8$ \\
Z. jujuba Seeds & $14 \pm 1.3$ \\
R. alaternus Leaves & $0.4 \pm 0.01$ \\
R. alaternus Bark & $1.8 \pm 0.01$ \\
BHA & $0.1 \pm 0.0$ \\
\hline
\end{tabular}

\subsection{Hemolytic activity}

The results obtained show that the percentages of hemolytic effect are directly proportional to the increase in concentrations and as a function of time ( 0 to $60 \mathrm{~min}$ ) (Figures 5 to 8$)$. 
Bulletin de la Société Royale des Sciences de Liège, Vol. 89, 2020, articles, p. 1 - 14

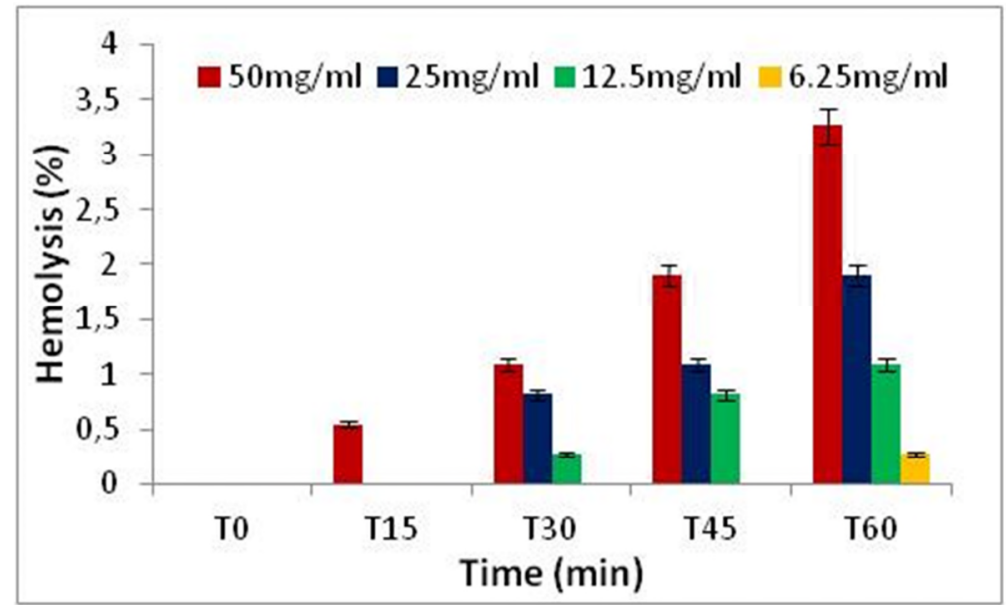

Figure 5: Hemolytic effect of Z. jujuba fruit extract, expressed as a percentage, at different concentrations and as a function of time.

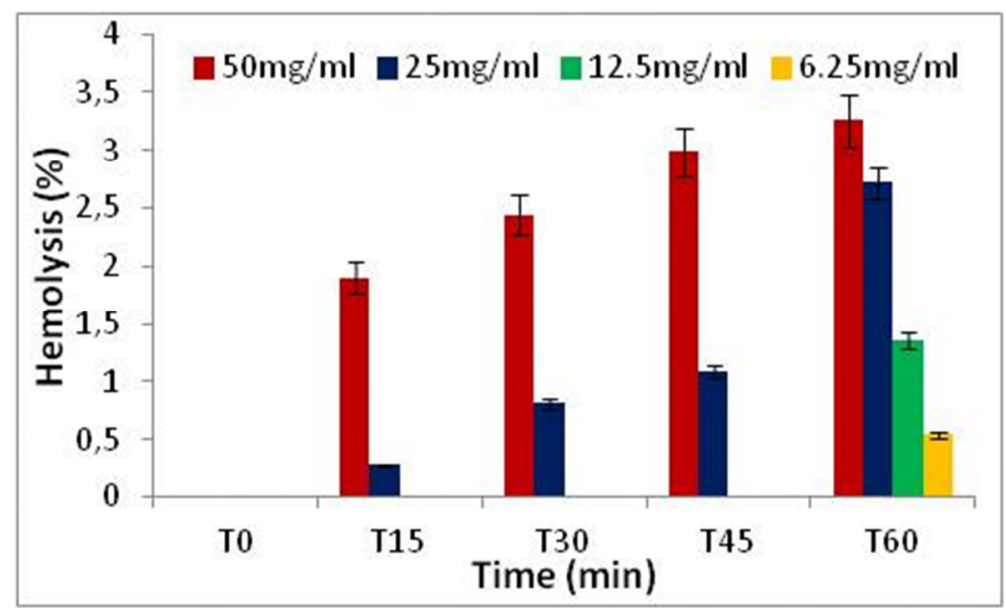

Figure 6: Hemolytic effect of $Z$. jujuba seed extract, expressed as a percentage, at different concentrations and as a function of time.

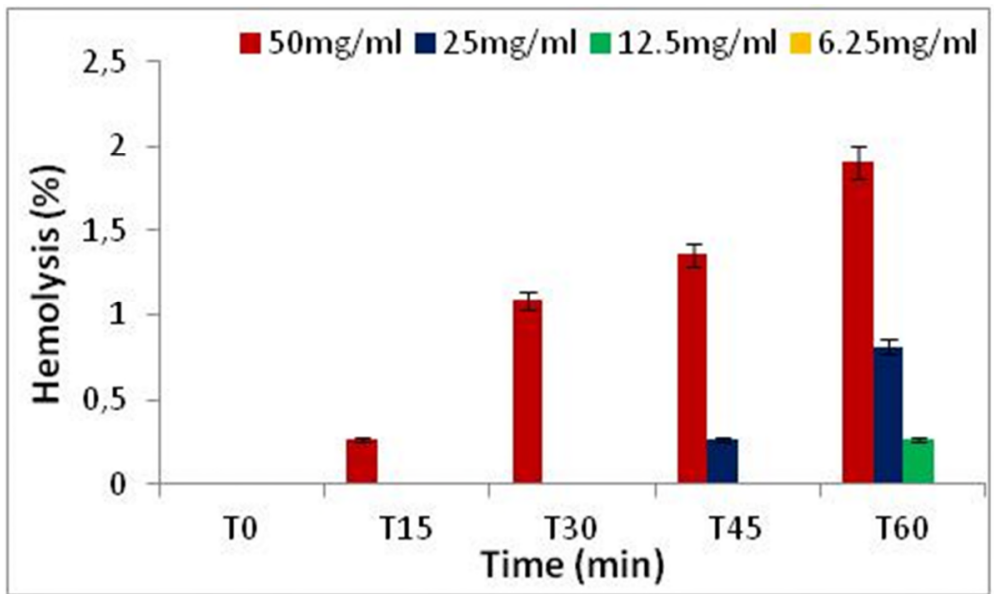

Figure 7: Hemolytic effect of $R$. alaternus leaves extract, expressed as a percentage, at different concentrations and as a function of time. 


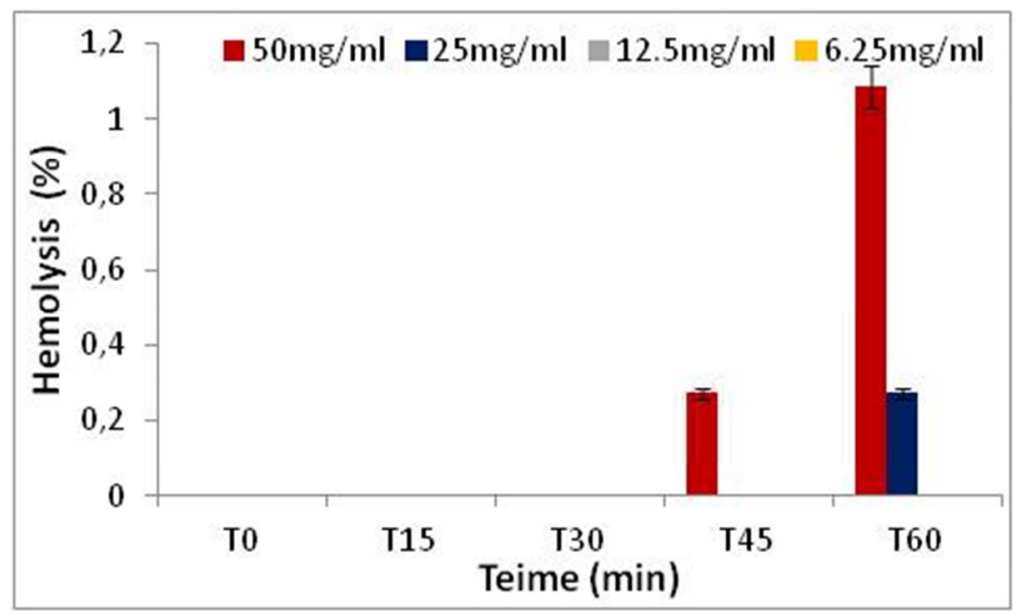

Figure 8: Hemolytic effect of $R$. alaternus Bark extract, expressed as a percentage, at different concentrations as depending of the time

\section{DISCUSSION}

Many experimental investigations have demonstrated that a number of secondary metabolites, such as polyphenol compounds, extrated from medicinal and aromatic plants possess a high antioxidant potential, due to their hydroxyl groups and protect more efficiently against some free radical-related diseases [14].

According to Zhang et al. [15], the results obtained in the determination of polyphenols and flavonoides on several extracts from different parts of Z. jujuba Mill (the skin of the fruits, the pulp and the seeds) were between 2.28 to $32.80 \mathrm{mg}$ GAE/g DM and 1.58 to $18.51 \mathrm{mg}$ EQ/g DM, respectively. According to Kosalec et al. [16] the result obtained on the content of total polyphenols and flavonoids on the extract of $R$. alaternus Lis around $38.4 \mathrm{mg}$ GAE/g DM and $33.6 \mathrm{mg} \mathrm{EQ} / \mathrm{g} \mathrm{DM}$, respectively. According to the results obtained by Ben Ammar et al. [17], on the aerial part of $R$. alaternus from Tunisia, the content of tannins in the methanolic extract was expressed as a percentage of tannic acid, was around $14.72 \%$. These Contents remain higher than the contents obtained in our work. This difference can be explained by the region in which the plant is grown, the nature of the extraction solvents used, the dosing method, calibration curves used (quercetin, rutin, cathechin) and the parts of the plants studied, reduce the reliability of the comparison between studies.

According to the study by Al-Reza et al. [18] on the antioxidant activity by the DPPH radical method on $Z$. jujuba, the $\mathrm{IC}_{50}$ of the methanolic extract of the order of $18.60 \mu \mathrm{g} / \mathrm{ml}$. The same study by Ben Ammar et al. [19] on the bark of roots and leaves of the $R$. alaternus from Tunisia showed IC50 of $7.21 \mu \mathrm{g} / \mathrm{ml}$ and $19.84 \mu \mathrm{g} / \mathrm{ml}$, respectively. This result shows that there is a stronger antioxidant activity than those found in our work. This can be explained by the geographic location of the plant as well as the harvest season.

The hemolysis test was evaluated because, even if a plant has antioxidant power, its use in traditional medicine and in pharmacological preparations will be impossible in the presence of their hemolytic effect, which is an indicator of cytotoxicity $[7,20]$.

We note that all the extracts have no percentage of hemolysis in time 0 , after 15 minutes and 30 minutes of contact with the erythrocytes, there is a slight increase in the 
percentages in the two extracts of $Z$. jujuba and in the extracts of the leaves of $R$. alaternus, at a concentration of $50 \mathrm{mg} / \mathrm{ml}$. On the other hand, in the extract of the bark of $R$. alaternus, no hemolytic effect is recorded even after 30 minutes. After 60 minutes of contact with human erythrocytes, maximum hemolysis $(3.26 \%)$ is obtained in the two extracts of Z. jujuba, followed by the extract from the leaves of $R$. alaternus $(1.9 \%)$. and finally the extract of the bark of $R$. alaternus $(1.08 \%)$. At a concentration of $50 \mathrm{mg} / \mathrm{ml}$, all the extracts represent a very weak hemolytic effect. As a result, the results of the hemolytic power of the extracts show that all of the extracts studied represent a haemolytic effect of less than $3.5 \%$ after 1 hour of contact with human erythrocytes, which could explain or low content of saponins in the extracts [21].

On the other hand, it is important to note that the $\mathrm{IC}_{50}$ or $\mathrm{EC}_{50}$ values found in the evaluation of the antioxidant activity of the extracts from two plants (Table 1 and 2), do not exceed a concentration of $14 \mathrm{mg} / \mathrm{ml}$, whereas at this concentration, the hemolysis does not exceed $1.2 \%$.

\section{Conclusion}

The results of this in vitro study are only a first step in the search for biologically active natural substances. A study of the antioxidant and hemolytic properties concerned two plants, belonging to the family of Rhamnaceae, These are Ziziphus jujuba Mill and Rhamnus alaternus L, two Mediterranean plants that are used in the traditional pharmacopoeia, for the treatment of several diseases. Quantitatively, the evaluation of the content of total phenols, on the extracts gave values expressed in gallic acid equivalent between $0.64 \pm 0.03$ and $2.05 \pm 0.1 \mathrm{mg}$ GAE$/ \mathrm{g}$ MS. In the same way, we measured the flavonoids and the condensed tannins, the contents obtained in the flavonoids and the tannins were expressed in Catechin equivalent are in the order of $0.01 \pm 0.001$ to $0.99 \pm 0.01 \mathrm{mg} \mathrm{EC} / \mathrm{g} \mathrm{DM}$ and $0.55 \pm 0.01$ to $7 \pm 0.2 \mathrm{mg}$ EC/g DM respectively. The study of antioxidant activity varies from one extract to another.

The extracts reveal an activity of the radical DPPH lower than that of the antioxidant from the BHA indust ry $\left(\mathrm{IC}_{50}=5.6 \pm 0.8 \mu \mathrm{g} / \mathrm{ml}\right)$. This same antioxidant exhibited a higher activity than that of the extracts according to the FRAP method $\left(\mathrm{EC}_{50}=0.1 \pm 0.0 \mathrm{mg} / \mathrm{ml}\right)$. But the $R$. alaternus $\mathrm{L}$ leaves have the best antioxidant activities with respect to all other parts of the plants. In the end, the study of the hemolytic power on the studied extracts showed results of less than $3.5 \%$, which explains why the extracts are not toxic.

This preliminary work can be implemented by other more in-depth studies, for that purpose the following investigations are recommended:

1. Widening the panel of in vitro and in vivo tests of antioxidant activity specially for R.alaternus L. leaves extracts.

2. Studying other biological activities (antimicrobial, anti-inflammatory, hepatoprotective ).

3. Developing a fractionation strategy to isolate the active molecules by chromatographic techniques leading to their identification by spectrometric methods.

4. Testing purified molecule(s) or extracts in food systems with the goal to replace synthetic antioxidants that are continuously suspected harmful to human health.

5. Finally, it is essential to study the cytotoxicity of these molecules in order to confirm their adequacy as additive in different human food products. 


\section{REFERENCESS}

1. Ali-Rachedi F., Meraghni S., Touaibia N., Sabrina M. (2018). Analyse quantitative des composés phénoliques d'une endémique algérienne Scabiosa Atropurpurea sub. Maritima L. Bulletin de la Société Royale des Sciences de Liège. 87: 13 -21.

DOI: $10.25518 / 0037-9565.7398$.

URL : https://popups.uliege.be:443/0037-9565/index.php?id=7398

2. Mangambu MJ., De D., mushagalusa KF., kadima NJ. (2014). Contribution à l'étude phytochimique de quelques plantes médicinales antidiabétiques de la ville de Bukavu et ses environs (Sud-Kivu, R.D. Congo). Journal of Applied Biosciences. 75:6211-6220.

3. Haddouchi F., Zerhouni Kh., Sidi-Yekhelef A.. Chaouche Tarik Mohammed. (2016). Évaluation de l'activité antimicrobienne de différents extraits d'Helichrysum stoechas subsp. rupestre. Bulletin de la Société Royale des Sciences de Liège. 85: 152-159. URL : https://popups.uliege.be:443/0037-9565/index.php?id=5894

4. Gao QH., Wu PT., Liu JR., Wu CH., Parry JW., Wang M. (2011). Physicochemical properties and antioxidant capacity of different jujube (Ziziphus jujuba Mill.) cultivars grown in loess plateau of China. Scientia Horticulturae. 130(1)

: 67-72.

5. Damiano S., Forino M., De A., Vitali LA., Lupidi G., Taglialatela-Scafati O. (2017). Antioxidant and antibiofilm activities of secondary metabolites from Ziziphus jujuba leaves used for infusion preparation. Food Chemistry. 230: 24-29.

6. Cuoco G., Mathe C., Vieillescazes C. (2014). Liquid chromatographic analysis of flavonol compounds in green fruits of three Rhamnus species used in Stil de grain. Microchemical Journal. 115: 130-137.

7. Chaouche TM., Haddouchi F., Atik-Bekara F., Ksouri R., Azzi R., Boucherit Z., Tefiani C., Larbat R. (2015). Antioxidant, haemolytic activities and HPLC-DAD-ESI-MSn characterization of phenolic compounds from root bark of Juniperus oxycedrus subsp. oxycedrus. Industrial Crops and Products. 64:182-187.

8. Vermerris W. (2006). Phenolic compound biochemistry. Springer. Dordrecht. ISBN-10 14020-5163-8 (HB).

9. Dewanto, V. X., Wu, K., Adom, K., Liu, R. H. (2002). Thermal processing enhances the nutritional value of tomatoes by increasing total antioxidant activity. Journal of Agricultural and Food Chemistry, 50, 3010-3014.

10. Sun B., Richardo-da-Silvia J.M., Spranger I. (1998). Critical factors of vanillin assay for catechins and proanthocyanidins. Journal of Agricultural and Food Chemistry, 46(10): 42674274. 
11. Prieto P., Pineda M., Aguilar M. (1999). Spectrophotometric quantitation of antioxidant capacity through the formation of a phosphomolybdenum complex: specific application to the determination of vitamin E. Analytical Biochemistry 269(2):337-341.

12. Pan Y., Wang K., Huang S., Wang H., Mu X., He C., Ji X., Zhang J., Huang F. (2008). Antioxydant activity of microwave-assisted extract of longan (Dimocarpus Longan Lour.) peel. Food Chemistry. 106(3):1264-1270.

13. Guo-Xiang L, Zai-Qun L. (2008). The protective effects of ginsenosides on human erythrocytes against hemin-induced hemolysis. Food and Chemical Toxicology. 46(3):886892.

14. Vaya J., Mahmood S., Goldblum A., Aviram M., Volkova N., Shaalan A., Musa R., Tamir S. (2003). Inhibition of LDL oxidation by flavonoids in relation to theirstructure and calculated enthalpy. Phytochemistry. 62(1): 89-99.

15. Zhang H., Jiang L., Ye S., Ye Y., Fazheng R. (2010). Systematic evaluation of antioxydant capacities of the ethanolic extract of different tissues of jujube (Ziziphus jujuba Mill.) from China. Food and chemical toxicology. 48(6): 1461-1465.

16. Kosalec I., Kremer D., Locatelli M., Epifano F., Genovese S., Carlucci G., Randic M., Zovko koncic M. (2013). Anthraquinone profile, antioxidant and antimicrobial activity of bark extracts of Rhamnus alaternus, R. Fallax, R. intermedia and $R$. pumila. Food chemistry. 13(2): $335-341$.

17. Ben Ammar R., Kilani S., Bouhlel I., Skandarani I., Naffeti A., Boubaker J., Ben Sghaier M., Bhouri W., Mahmoud A., Chekir-Ghedira L., Ghedira K. (2007). Antibacterial and cytotoxic activities of extracts from (Tunisian) Rhamnus alaternus (Rhamnaceae). Annals of Microbiology. 57(3): 453-460.

18. Al-Reza SM., Bajpai VK., Kang SC. (2009). Antioxidant and antilisterial effect of seed essential oil and organic extracts from Zizyphus Jujuba. Food and chemical toxicology. 47(9): 2374-2380.

19. Ben Ammar R., Kilani S., Bouhlel I., Ezzi L., Skandrani I., Boubaker J., Ben sghair M., Naffeti A., Mahmoud A., Chekir-Ghedira L., Ghedira K. (2008). Antiproliferative, antioxidant and antimutagenic activities of flavonoides Enriched extracts from (Tunisian) Rhamnus alaternus L.: combination with the phytochemical composition. Drug and chemical toxicology. 31(1): 61-80.

20. Haddouchi F., Chaouche TM., Halla N. (2018). Screening phytochimique, activités antioxydantes et pouvoir hémolytique de quatre plantes Sahariennes d'Algérie. Phytothérapie. 16(1S): 254-262. 
21. Sharma, P., Sharma, J.D. (2001). In vitro hemolysis of human erythrocytes by plantextracts with antiplasmodial activity. Journal of ethnopharmacology. 74, 239-243. 